\title{
The Relevance of Master Degree Programs in Enhancing Employability in Tanzania: A case of Makete and Mbeya Districts
}

\author{
Norman A. S. King \\ St. John University and University of Dodoma \\ Jane Edward King \\ Mkwawa University College, Iringa
}

\begin{abstract}
Education is critical for the development of any countries the world over. In this regard, various levels of education certification have been created for the purpose of improving people's knowledge and hence be able to master their environment. The levels are many, and include bachelor, master and doctor of philosophy degrees. Irrespective of these various degrees, the paramount question is the extent to which these degree can facilitate employability both self-employment and being employed by second part. This study seeks to find the role of master degree in creating employability. The study utilizes interview, documentation, experiential and observation as the major information collection strategies. The analysis of the findings has used content analysis, which apprehends logical reasoning through systemic thinking. It is a multi- case study design as it incorporates two districts of Mbeya and Makete. 24 workers have been subjected in the study. 11 from Mbeya city council, 9 from Mbeya district council, and 4 from Makete district. The sample has included only workers from each council who hold a master degree. Hence, the total sample was 24. This was 96 percent of the workers with master degree at these councils. Percentiles and relevant analytical tools have been used to provide required information for consumption of the entire world through analysis. The paper concludes that $2 \%$ of the interviewed indicated that master degree programs does facilitate self-employment. $12 \%$ indicated that master degree does create employment in central and local government. Generally, an average of $26.6 \%$ indicated that master degree does create employability, while $\mathbf{7 3 . 4 \%}$ indicated that master degree program does not create employability. We therefore suggest that it is imperative for the turnaround on the programs we teach at university levels for the purpose of providing relevant knowledge which provides answers to the problems we face in our societies and thus enable graduates to have ability for selfemployment and or be employed.
\end{abstract}

Keywords: Employability, Master degree, developing countries, local and central government.

\section{INTRODUCTION}

Formal education is crucial for creating enlighten to the people. Countries the world over have been striving at boosting education for the purpose of creating employment to the people among others. In this regard, King (2016) and UN(2017) asserts that education is crucial for the development of our countries. He adds that proper education can be weighed through its ability to create employment to the people. Several authors have put in place literatures regarding the importance of education. What is evident few literature have made a relationship on the extent to which formal education can facilitate employment in African context. Norman and Mdegella (2013) indicate that education must provide answers to the problems we face in our daily activities. What is evident is that at times our education as revealed through our graduates, does not provide answers to the challenges we face in our societies (King, 2015). Therefore we need to think critically to find out what is the cause of the situation. We have over 100 thematic of bachelor's degree in East Africa. And of course more than that number as we reflect African context. The issue of concern is, to what extent the types of programs in 
terms of degrees do provide answers to the readily available challenges of the society? We have taught several years in universities all over the world, and we have continued to ask ourselves one paramount question. Are we in the right track in the way we recruit lecturers, and thus the value of what we offer to the students? Can we claim the validity of contribution of master degree to the performance of the councils and or even the central government?

Is what we offer to the students sufficient to provide them with competencies required on job or other jobs that would be created for the sake of transforming the societies? If not, what should we do to improve the situation? This paper provides findings on the study that was meant to realize the relevance of Master program to the workers of district council of Mbeya city and Mbeya district councils. We wanted to know if they were relevant and were helpful in enhancing the works of the local government council. We ultimately wanted to realize what would have happened if the programs pursued would not have been pursued.

Generally, a postgraduate qualification is an important commitment that requires discipline and dedication. It is often the next step on the professional ladder after studying a bachelor's degree, and can be a worthwhile investment for future if tailored to mitigate the challenges we face in our societies (Norman, 2015).

Postgraduate studies will generally help to develop important transferable life skills - such as public speaking, research skills, presentation and report writing. It is therefore important that one choose a master's degree carefully, and select a course that benefits and is relevant to the desired career path. There is several dimension regarding the role of degrees to the majority people in the world and probably the education career. Some look at education, especially degrees as a course to provide an enlighten for one to be able to realize the problems and thus acquire necessary skills to solve the same. Some consider bachelor degree as general course of study which does not provide mastery skills but general knowledge on the thematic area. However, whether the degree is general or specific, it has to provide solutions to the problems of the required environmental setting. That is why improving the quality education of the programs we offer is very important (McQuillen, 1982). Although McQuillen seem to make an emphasis on the military training, but the essentials for training remain to be valid to all societies. Hence a need to study on the relevance of master programs to our societies, and in the near future justify if what we spend in the study renders value for money or not.

Some authors have come up with (Karodia,2013:2506) provide that MBA programs were created in the 1920s because large corporations felt that new employees lacked general management skills, and as a result, many talented recruits had to be taught on the job, the basics of business such as accounting, finance, market research and so on. With developments of management of various activities the world over, master programs have continued being designed to provide master knowledge to the students on how best could they articulate the challenges of the work and provide answers to it. Mostly through employment.

The current information on the rate of employability of African youth is alarming. The report on employment which was conducted in The Hague, Netherlands indicate some important information. It reveals that "Africa is the most youthful continent in the world, with 226 million youth (aged 15-24) in 2015 - which is roughly 20\% of the global youth population. While youth populations in other regions of the world have stabilized, Africa's youth population is growing rapidly and is expected to increase by $42 \%$ by 2030 . At the same time, youth in Africa face significant economic challenges, accounting for $60 \%$ of all unemployed in Africa. Hence, youth employment is a top priority for Africa" (INCLUDE, 2017). 
This provides another important information as to whether the problems of unemployment in Africa should be left to the few or the majority people should think big on how best can come up with measures to eradicate or reduce unemployment rate. In this regard the chairman of African Union Commission had this to say, "the future of Africa belongs to youth, but the quality of that future will be determined by what they do with it today (Dhlamini-Zuma, 2017). This necessarily require young people who have acquired the rightfully education, which include skills and knowledge from educational institutions.

The quality of education beamed to the heads of state of the entire world, which lead the United Nations to come up with Sustainable Development Goals which are meant to be realized by 2030 . The fourth goals of sustainable development goals which were adopted in 2012 have placed an emphasis on the quality education which include remission of proper skills, knowledge, and altitude. Proper skills that will enable the recipient to demonstrate skillfully through responding to the challenges of the society. Knowledgeable in the sense of being able to be the answer of the challenges that societies face, which include proper understanding of the issues pinning the society. Altitude in the sense of knowledges and skills that have shaped the recipient to the extent of differentiating from the rest of those not received such education.

The report of sustainable development goals of 2017 reveal further that, "SDGs aims to ensure that all people have access to quality education and the opportunity for lifelong learning. The Goal goes beyond school enrolment and looks at proficiency levels, the availability of trained teachers and adequate school facilities, and disparities in education outcomes"(UN, 2017:4).

Henceforth the need to pursue a study to find out the extent to which master degree is relevant or irrelevant in creating employability to the graduates.

\section{Objectives of the study}

The main aim of the study was to find out the relevance of master degree in creating employment to those with a master degree.

The minor objectives were:

a) To find out if the acquisition of master degree contributed to the enhancement of employability of the graduates? This objective entails to capture self-assessment of the employees on the contribution of master degree to the employability.

b) To find out weaknesses if any of the master degree program, which once tackled would lead to positive contribution to the employability. This objective entails to assess perception of the interviewees on what is required for improving the master degree program if any for the purpose of creating employability.

c) To find out what general quality was noted among the master degree which promoted them or do promote them to be employed?

\section{Questions for the study}

The study came up with several questions which entailed to provide answers. The questions were many but the key questions for the purpose of reporting in the manuscript such as this are three.

a. What is the relevance of the master degree in creating employability in Tanzania?

b. What do you think are the areas that master degree has contributed if any, in the employability at work?

c. What do you consider to be the weakness of master degree you pursued that lead into not contributing to the enhancement of employability? 


\section{Importance of the study}

The study is important in setting an agenda for improving educational system all over the world, and specifically in developing countries such as Tanzania. It will further provide the extent of wastage of resources or the proper utilization of resources depending on what is true in the facets. This study will shape the courses and indicate the levels that are pertinent in the ability of such courses in enabling the graduate be employed.

\section{Methodological assumptions}

The following methodological assumptions were considered implicit in this investigation: 1 . the sample of respondents was sufficiently representative of the population to permit a reasonable degree of generalization of findings. 2. The participants answered accurately and honestly the items on the questionnaire. 3. The reliability and validity of the instrument used were sufficient to permit an accurate description and analysis of the resulting data. 4 . The data collected were interpreted fairly and accurately. 5. The design and sampling procedures were appropriate to the intent of the investigation. Procedures were appropriate to the intent of the investigation. The rest of the paper is divided into literature review, materials and methods, findings, analysis of the findings, conclusion and recommendation.

\section{LITERATURE REVIEW}

Employment is crucial if we want to boost the livelihood of the people. People who are employed tend to live comfortably with little stress compared to people who are qualified to be employed yet are not employed (King, 2009). Few literatures have covered the importance of master degree in creating employability. Most of the literatures seem to cover the importance of education, and some the importance of master degree. In this regard, King (2017) reveals that most local government employees have feeling that master degree does not help them in acquiring knowledge sufficient to improve work at their places. RMI provides that "master degree could not help me on tackling the problems that I faced prior to attending the course. Earlier I thought it could make something especially in improving the work, but it could not" (King, 2017).

In the same vein, Norman (2015) adds that "no doubt many authors have researched on education. However, the researches on the relevance of master degree program or even bachelor's degree program are limited". Education refers to the set of knowledge that is accrued through various means of learning for the purpose of providing answers to the challenges that face our environment in ever changing world (King, 2011:28). Master degree emanates from competence based character as opposed to bachelors. Master program simply means champion of the named thematic area. The programs were designed to provide ability of personnel to master their works as opposed to first degree which entailed to provide general knowledge on the theme.

In all senses, we notice that master degree was created to provide mastery knowledge for the purpose of enabling a holder of such degree be able to employ or be employed. Norman and Mdegella (2013) provide that education is a key to development if it responds positively to the challenges that we face in our societies.

In this view, it can be realized that education irrespective of what is articulated in the courses, it should indeed provide answers to the needs of the societies (Norman, 2005). Otherwise we could be investing huge amount of money without having the corresponding benefits of the same.

There are several types of master degree. However, in this study we concentrate on two types 
of master degrees. A taught course, which comprise of lectures and seminars that are divided by modules. They include master's courses and MBAs. Students tend to be assessed by exams, coursework and a dissertation. Beside all these efforts and certainly types of master degree, one would need to realize that needs assessment is crucial prior to the establishment of any master degree program (Rosset, 1987). In the same line we notice that human resource training is imperative in the enhancement of organizational success if and only if it responds to the needs of the society (Norman, 1997).

A research course will involve a lot more independent learning than a taught course. Doctorates are an example whereby students typically spend three to six years investigating a research project. Postgraduate studies allow you to learn alongside positive like-minded people. It is important that you have a mature attitude and take responsibility for your studies; employing independent thinking and decision making (Genesis, 2016; UDSM, 2013; OUT, 2012). Employers look favorably on candidates that can demonstrate skills and knowledge gained on a postgraduate course because it demonstrates your ability to think independently and develop a clear insight into an industry (Norman, 1997;

Whatever interpretation one may have regarding education, one thing is certain education is a vital and essential commodity for developing countries of the world in particular, irrespective of how and why one acquires this education (Karodia, 2013:2507). Higher education matters are essential because it transforms the lives of individuals, graduates are more likely to enjoy higher wages and better job satisfaction, and more likely to find it easier to move from one job to another (Browne Report, 2010).

Several authors have made vital contributions on the linkages between awards versus performance. Davies (1981) provides some important techniques of linking educational awards and the performance from the same. The emphasis on the literature is to quantify the need for an award, which is fruitful. Bedwell (1984) in his popular book effective teaching indicates the importance for effective teaching by evaluating what we teach and the performance of those who graduate from what we have taught. The purpose is to emphasize on the importance of teaching with the view to ripe what we teach. Larson (1970) provides that military training and education are imperative if they come up to bridge the gap between theory and praxis. McCord (1985) in his great book Methods and theories of instruction, reveals that there should be congruence between what we teach and term it theories versus instruction for the purpose of attaining optimal goals.

Generally, we ought to come up with prudent documents known as books and thus worthy for teaching when we give value to the needs assessment prior to launching any program. In this view Rossett (1987) indicate clearly on the importance of doing needs assessment in designing and formulating course of all types for the purpose of getting a clear picture on what should be included in the courses. Generally, we need to realize benefits of the graduates. We must reap fruits of the educated, and or education we have acquired. Profits are important for all businesses regardless of whether they are in the private or public sector; they are on service delivery or goods production. The very nature of business is to produce goods or services that you can sell for a financial profit or reward (Marr, 2012:3). In this regard, societies should reap the profits from those educated. It is from this stand point of view, it is imperative to find out the extent to which master degree can lead to employability. 


\section{MATERIALS AND METHODS}

The study employed a qualitative design approach. It used questionnaire, interview, and documentation as information collection tools in setting the agenda. The approach was a multi case study design where two districts were involved, which are Mbeya and Makete districts. The sample of the study was 24 employees who holds a master degree. 20 were from Mbeya and 4 from Makete. In Makete these were total number of employees holding master degree, hence it was $100 \%$ sample from the entire population of master degree holders. While in Mbeya this was $98 \%$.

The data collection strategies used were the interviews, questionnaires, observation and documentation. However, the dominant data collections strategy was questionnaire. The analysis of the information has used Nova 8, which does an analysis on contents. We have coded respondents as R1, to indicate respondents one from the sample, and R2 to indicate respondents two from the sample. We have treated the two cases as one study hence the analysis.

\section{FINDINGS OF THE STUDY}

The study on the relevance of master degree program in creating employability to the graduates has come up with interesting findings. The study has come up with some interesting findings which we could not predict before even if we wanted to. The total response of the workers indicated some diversified responses summarized in the table 1.1 below.

Table 1.1. Responses on employability of master degree graduates

\begin{tabular}{|l|l|l|l|l|l|}
\hline Ranking & Very irrelevant & Irrelevant & average & relevant & very relevant \\
\hline Males & 12 & 2 & 0 & 1 & 0 \\
\hline Females & 7 & 1 & 1 & & 0 \\
\hline Total & 19 & 3 & 1 & 1 & 1 \\
\hline
\end{tabular}

Source: Field data, 2017. Responses by sex on the relevance of master degree program in Mbeya. The findings indicate that 19 interviewee found that the master degree was very irrelevant in enabling employability of graduates. 3 interviewee noted that master degree was irrelevant. 2 noted that the master degree program was average. 2 respondent realized that master degree was relevant, and one respondent found that it was very relevant.

\section{Responses of interviewee}

Respondents on the first question, have indicated that master degree is very irrelevant in enabling employability to the graduates. $80 \%$ of male respondents indicated that master degree is very irrelevant in creating employability. This seems to conform to another study which sought to find out the relevance of master degree in boosting performance of local government workers.

When R2 was asked to respond on the open question he had this to say "I first applied for the university that has reputable perception in Tanzania. After I had graduated, I noted that I wasted time for the entire one half year, because I became a holder of certificate in the name of master degree but it did not impart knowledge worthy to help me pursue better my work".

Responses from R12 indicate that "master degree has helped me broaden my knowledge. I feel more confident compared to before, though it is not very much related with what I am doing here at the district council".

R3 had this to say, "Master degree of business administration has not been of importance to me. It does not answer the needs of my career. Certainly, I will pursue another degree to 
realize the worthiness".

R6 had this to say, "I have attained my MPA and am proud because now can protect my virtue of being a head of department. .. Really I cannot quantify the benefits of MPA because I am yet to cognize the benefits may be in future".

R14 had this to say, "I have seen the benefits of Master degree of economics and rural development, especially on some concepts regarding my work and the society am working with. I feel proud of new level of education."

Figure 1, provides a summary on the respondents and their responses on the relevance of master degree program in local government authorities in Tanzania.

\section{ANALYSIS OF THE FINDINGS}

The responses above paves a way to look in-depth on the interpretive meaning of each segment of responses. Table 1.1 sums up responses on the key question. What is the relevance of master degree in enabling employability in Tanzania?

The ranks were made on the basis of five points. With 1 indicating very irrelevant, 2 Irrelevant, 3 satisfactory, 4 relevant, and 5 indicating very relevant.

Generally coding 1 and 2 indicates irrelevance, while coding 4 and 5 indicate relevance. Coding 3 indicates satisfactory. Summing up the responses, we notice that 18 respondents indicate that the master degree was very irrelevant to the improvement of the performance of the council. This is about 60 percent of the total population sample. In addition, 8 percent indicates that the master degree was irrelevant to the improvement of the performance of the council, which is 26.7 percent of the total respondents. Moreover, 1 female indicated that the master program was relevant to the improvement of performance of the council, while 1 male indicated that the program was very relevant. Each of the two respondents account to 3.3 percent of the total responses.

Based on the interpretive nature, the 19 respondents (very irrelevant) and the 3 respondents (irrelevant) account to 22 (irrelevant) in total out of 24 respondents, which is $91.6 \%$.

The satisfactory account to $4.1 \%$ percent of the total respondents, which is 1 person.

We realize that generally the graduates of master degree who are working with the districts of Mbeya and Makete indicate that master degree program could not avail what could be termed contribution to the employability of the graduates in the named districts.

This could further bring forth two other propositions: 1) that the master degree program were not structured to suit the needs of both public and private sector in Tanzania 2) that the institutions of higher education have not sought to link the needs of the societies versus what is taught.

The named propositions need an in-depth study to articulate major master degree programs pursued by most students in Tanzania. The pertinence of the study lies on the fact that African countries strive at educating her people for the purpose of enabling them get employed or create employment opportunities. When the education acquired does not benefit the students, 
it becomes a burden to both the government, which has funded some of these students and the students and their families which have incurred cost in pursuing the education goal.

\section{CONCLUSION}

Understanding the importance of graduate programs is critical if we are keen in the use of public and private funds. People do not second their children for higher education as funny, not at all. People expects rewards and fruits of the graduates. Generally, one would expect that a master degree student will be a person who think independently and assume responsibility with high altitude of keen. The study indicate that most master degree students opine that master degree programs are irrelevant to the creation of employability of the graduates in Makete and Mbeya districts. $91.6 \%$ of the respondents opined against the master degree ability to create employment. $4.1 \%$ was in favor of the program ability to create ability of the graduates in getting employment. As noted in some other studies, the pertinence of the master degree program seem to rely on status of the graduates, credential for attaining promotion, and provide protection to heads of department on maintaining the positions they hold (King, 2017). We conclude therefore that there are crucial challenges that need to be mitigated by African governments Tanzania included, for the sake of creating packages that are worthy to enable graduates have ability to create jobs, or get jobs. The employability of the graduates depends solely on whether the programs comprehend with the needs of the private and public sectors. No one would employ people for funny. Employment is made for the purpose of achieving organizational goals. Hence the quality of the graduates are paramount. It is of crucially, that education institutions which is a supply side of human resources as commodities or products, and private and pubic sectors which are the demand side of the products to harness the programs that are demand driven. We should not verge into recycling same knowledge while the pace of development of both technology used in production and the products are changing daily.

\section{ACKNOWLEDGEMENTS}

I would like to appreciate the participation of the employees and management of Mbeya and Makete districts. Their participation have made this study possible. Secondly, I would like to appreciate the current president of Tanzania, Dr. John Pombe Magufuli for his vision to ensure Tanzania is industrialized. This strand, necessarily provoked the author to see the extent to which a master degree program is in support of the vision or not. Finally, writing requires skills and knowledge, and the founder and the finisher of authorship is God, to Him be the Glory.

\section{References:}

Bedwell I.E (1984). Effective teaching. Springfield, IL: Charles C. Thomas. Brodsky N (1970). The armed forces. In R. M. Smith, G. F. Aker, and J. R. Kidd (Eds.), Handbook of adult education. New York: Macmillan.

Davies I.K (1981). Instructional Technique. New York: McGraw-Hill.

Karodia, A.M (2013). A critical commentary on the business education debate in South Africa: The Master of Business Administration Degree (MBA) versus the Master of Arts Degree in Philosophy (MA). African Journal of Business management. Vol. 7(26), pp. 2506-2513,

INCLUSIVE (2017). The report on unemployment in Africa. The Hague: Netherlands.

King, N.A.S. and Mdegella, O.M (2013). The impact of market education driven policy in in the provision of education in Tanzania. International Journal of Marketing, Financial Services \& Management Research. Vol.2, No. 5, May (2013)

King, NAS (2017). African Development Bailout some strategies for development. Bookbaby: New York.

Larson, G (1970). Military education and training. In J. M. Grabowski (Ed.), Strengthening connection between education and performance. San Francisco, CA: Jossey-Bass.

Marr, B (2012). Key Performance Indicators: The 75 measures every manager needs to know. Pearson Education 
Limited: Great Britain.

McCord, M.T (1985). Methods and theories of instruction. In J. C. Smart (Ed.), Higher Education Handbook of Theory and Research. (pp. 97-133) New York. Agatnon Press.

McQuillen, C.D (1982). Improving the quality of military education programs. Performance and Instruction, 21, 19-21.

Norman, A.S (2011). The role of education in boosting development: Thinking systemically. International Journal of education administration and policy studies. Vol.2 (3), pp.28-32

Norman A.S (1997). Human Resource Training as a Tool for Organizational Success. IDM, Mzumbe

Salwa Tawfik Abd Al Azeem, Eman Taher Elsayed, Naglaa Abd El Khalek El Sherbiny, and Lamiaa Abd El Gawad ahmed(2011). Promotion of knowledge and attitude towards premarital care: An interventional study among medical student in Fayoum University. Journal of Public Health and Epidemiology Vol. 3(3), pp. 121-128

Rossett A (1987). Training Needs Assessment. Englewood Cliffs, NJ: Educational Technology Publications. Szczypkowski R (1980). Objectives and activities. In A. B. Knox (Ed., Developing, administering, and evaluating adult education. (pp. 37- 74). San Francisco, CA: Jossey-Bass.

United Nations (2017). The report of sustainable development goals. United Nations: New York. 